\title{
Use of Water Soluble and Phosphorescent MPA- capped CdTe Quantum Dots for the Detection of Urea
}

\section{Üre Tayini için Suda Çözünebilen ve Fosforesan MPA Kaplı CdTe Kuantum Noktacıklarının Kullanımı}

\author{
(D) Tülay OYMAK ${ }^{1 *}$, (D) Nusret ERTAŞ², (D) Uğur TAMER² \\ ${ }^{1}$ Cumhuriyet University, Faculty of Pharmacy, Department of Analytical Chemistry, Sivas, Turkey \\ ${ }^{2}$ Gazi University, Faculty of Pharmacy, Department of Analytical Chemistry, Ankara, Turkey
}

\begin{abstract}
Objectives: To describe a method for the determination of urea in blood serum using urease enzyme and 3-MPA-capped CdTe quantum dots.

Materials and Methods: The method is based on the increase in $\mathrm{pH}$ of the solution as a result of the reaction between urea and urease, which causes an increase in the phosphorescence signal of MPA-CdTe quantum dots in the $\mathrm{pH}$ range of 2.5-5.0. Under the optimum conditions, the linear range of urea was $0.016-0.16 \mathrm{mM}(1-10 \mathrm{mg} / \mathrm{L})$ and the limit of detection based on $3 \mathrm{~s} / \mathrm{b}$ was calculated as $0.003 \mathrm{mM}(0.17 \mathrm{mg} / \mathrm{L})$. The relative standard deviation was calculated as $3.4 \%$ at $4 \mathrm{mg} / \mathrm{L}$ urea concentration $(\mathrm{n}=7)$.

Results: The method was applied to human serum samples. The same samples were analyzed by an independent laboratory and the results were not statistically different, at 95\% confidence level ( $F$ test).

Conclusion: The proposed method does not need sample pretreatment, is simple, selective, and cost-effective for the determination of urea in serum samples.
\end{abstract}

Key words: Phosphorescent quantum dots, MPA-capped CdTe, urea

\section{ÖZ}

Amaç: Bu çalıșmada 3-MPA kaplı CdTe kullanılarak üre tayini için yöntem geliștirilmiștir.

Gereç ve Yöntemler: Yöntem üreaz enzimi ile ürenin reaksiyonu sonucu üretilen amonyağın ortam pH'sini değiştirmesi esasına dayanmaktadır. MPA kaplı CdTe'nin fosforesans sinyali pH 2.5-5.0 arasında üre konsantrasyonuyla doğrusal olarak artmaktadır. Optimum koşullar altında doğrusal aralık 0.016-0.16 mM (1-10 mg/L) gözlenebilme sınırı 3 s/b formülüne göre 0.003 mM (0.17 mg/L) olarak hesaplanmıştır. Bağıl standart sapma, 4 mg/L üre konsantrasyonunda \%3.4 olarak hesaplanmıștır ( $n=7$ ).

Bulgular: Yöntem serum numunesine başarılı bir şekilde uygulanmıştır. Aynı serum numuneleri bağımsız bir laboratuvar tarafından analiz edilmiş ve sonuçlarda \%95 güven aralığında istatistiki fark görülmemiștir ( $F$ testi).

Sonuç: Önerilen yöntem serumda üre tayini için, örnek ön hazırlı̆ı̆na ihtiyaç duymayan, basit, seçici ve düşük maliyetlidir.

Anahtar kelimeler: Fosforesan kuantum noktacık, MPA kaplı CdTe, üre

\section{INTRODUCTION}

Urea, which is an end product of protein metabolism and the main nitrogen component of urine, is an important biomarker monitored in blood and urine samples to diagnose renal and liver diseases. Urea concentrations above the normal level can be an indication of renal failure, urinary tract obstruction, and gastrointestinal bleeding. ${ }^{1,2}$ Conversely, low urea concentrations may be observed in hepatic failure, nephritic syndrome, and cachexia. Therefore, it is essential to develop techniques for the determination of urea in blood. Conventional spectroscopic methods have been used for many years in clinical laboratories for the determination of urea in blood samples. ${ }^{3-5}$ However, these methods are time consuming due to sample pretreatment and an unsuitable real-time determination of urea. Ureasebased biosensors are alternative methods for the determination of urea levels. ${ }^{6}$ To this end, a number of methods have

*Correspondence: E-mail: tulayoymak@cumhuriyet.edu.tr, Phone: +90 5058086779 ORCID-ID: orcid.org/0000-0001-5820-1364 Received: 14.01.2017, Accepted: 23.03.2017

๑Turk J Pharm Sci, Published by Galenos Publishing House. 
been developed and reported such as potentiometry ${ }^{7-9}$, voltammetry $^{10,11}$, conductometry $y^{12-14}$, ion selective electrode ${ }^{15}$, and spectrometry. ${ }^{16,17}$

Quantum dots (QDs) are superior to organic dyes with their size-tunable photonic properties, quantum yield, and stability against photobleaching. ${ }^{18-21}$ The luminescence properties of QDs are highly sensitive to changes on their surface. The majority of QD photoluminescent probes are based on the increasing or quenching of the photoluminescence signal, which is caused by chemical or physical interaction. Thus the selective determination of an analyte can be achieved via interaction with functionalized QD or non-functionalized QD. ${ }^{22-25}$

QDs have been widely used as biosensors in biotechnology. ${ }^{24-27}$ Recently, a few applications of QDs for the determination of urea appeared in the literature. ${ }^{6,17,24}$ All of these studies are based on the $\mathrm{pH}$ change upon the reaction of urea and urease. Although most previous studies have been focused on QDs as a fluorescence sensor, their long lifetime allows the use of the phosphorescence mode, which has more advantages than fluorescence; for example, the spectral interferences from biologic matrices can be easily prevented in the phosphorescence mode. 6,28,29

This study describes a simple and reliable analytical method for the determination of urea in biologic samples using 3-mercaptopropionic acid (MPA)-capped cadmium telluride (CdTe) QDs. The urea concentration was determined in serum samples by monitoring the increase in phosphorescence signal in the presence of urease.

\section{EXPERIMENTAL}

\section{Materials}

All the measurements were performed using analytical grade chemicals. Deionized water was used throughout the study. $\mathrm{CdCl}_{2}, \mathrm{H}_{2} \mathrm{TeO}_{6}, \mathrm{NaBH}_{4}, \mathrm{NaOH}, \mathrm{HCl}$, and urease were obtained from Merck, and the MPA was obtained from Fluka. Trisodium citrate was obtained from Riedel de Haen and ethanol was obtained from Sigma-Aldrich. Dilute solutions of the QD, urease, and urea were prepared daily.

\section{Apparatus}

A Varian, Cary Eclipse Luminescence spectrometer equipped with a xenon lamp was used for photoluminescence measurements. All instrumental parameters were controlled using the instrument software. The automatic filter selection mode for both excitation and emission monochromator was used to avoid scattered light. Excitation and emission spectral band passes were $20 \mathrm{~nm}$ for both monochromator. The detector voltage was set to $800 \mathrm{~V}$. An Orion 720. A model $\mathrm{pH} /$ lonmeter was used for $\mathrm{pH}$ adjustments. Deionized water with $18.2 \mathrm{M} \Omega . \mathrm{cm}$ was obtained from Millipore Simplicity water purification system. A Nüve NF200 centrifuge and Nüve MK418 magnetic stirrer were used during the synthesis of the QDs. Unicam Mattson 1000 Fourier transform infrared (FTIR) spectrometer was used to obtain IR spectra of the modified QDs to confirm surface modification. The ultraviolet (UV) spectrum of QDs was obtained using a Shimadzu UV- visible (VIS) spectrometer. Transmission electron microscopy (TEM) measurements were performed on a JEOL 2100 HRTEM instrument (JEOL Ltd., Tokyo, Japan). TEM samples were prepared by pipetting $10 \mu \mathrm{L}$ of $\mathrm{QD}$ solution onto copper grids, which were allowed to stand for $10 \mathrm{~min}$.

\section{Synthesis of water-soluble MPA-CdTe QDs}

MPA-CdTe QDs were synthesized using a modified method of Yuan et al. ${ }^{30}$ In the method, $25 \mathrm{~mL} 0.64 \mathrm{mM} \mathrm{CdCl}$, solution and $0.10 \mathrm{~g}$ of trisodium citrate was transferred into a single-necked flask. Then, $100 \mu \mathrm{L}, 11.5 \mathrm{M}$ MPA and $0.01 \mathrm{mmol}$ Te (IV) were added respectively, with continuous stirring. The color of the solution becomes bright yellow with the addition of $50 \mathrm{mg}$ of $\mathrm{NaBH}_{4}$, and it is heated to $90^{\circ} \mathrm{C}$ for 1 hour with continuous stirring. After cooling, QDs were precipitated with ethanol, centrifuged and dried in vacuum. Each batch resulted in $80-100 \mathrm{mg}$ of dry QD powder, and in order to have a constant QD concentration, a 75-mg portion of the QD powder was re-dissolved in water and diluted to $25 \mathrm{~mL}$ volume. At this stage, the $\mathrm{pH}$ of the QD solution was adjusted to 11.4 and heated to $96-100^{\circ} \mathrm{C}$ for a different period of time. An increase in particle size as well as fluorescence emission at longer wavelength was observed.

\section{Procedure for urea determination}

Ten milliliters of $3.0 \mathrm{mg} / \mathrm{mL}$ MPA-CdTe and $10 \mathrm{~mL}$ of 5 units/ $\mathrm{mL}$ urease solutions were placed into a beaker and the $\mathrm{pH}$ was adjusted to 2.5 with $0.01 \mathrm{M} \mathrm{HCl}$. The solution was transferred to a 25-mL volumetric flask and diluted to volume with deionized water. A series of standard solutions was prepared by transferring $1.0 \mathrm{~mL}$ of the mixture solution into a test tube and then various volumes of urea standard solution or $0.10 \mathrm{~mL}$ of serum samples were added. The volume was completed to 5.0 $\mathrm{mL}$ with deionized water. The solutions were mixed and allowed to stand for $10 \mathrm{~min}$ at laboratory temperatures. Measurements were performed using the phosphorescence mode with a $0.1 \mathrm{~ms}$ delay time and $3 \mathrm{~ms}$ gate time. Excitation wavelength was 300 $\mathrm{nm}$ and spectral band passes were $20 \mathrm{~nm}$ for both excitation and emission monochromators.

\section{Samples}

Human serum samples were collected from healthy volunteers. The samples were diluted 50 times with deionized water adjusted to $\mathrm{pH} 2$ with $0.01 \mathrm{M} \mathrm{HCl}$ before the measurement procedure. The same samples were analyzed for urea using standard methods used in clinical laboratory in order to test the accuracy of the proposed method.

\section{RESULTS AND DISCUSSION}

\section{Characterization of MPA-CdTe QDs}

The QDs were characterized using fluorescence, UV-VIS, infrared spectroscopy, and TEM images. After the synthesis procedure (without thermal pretreatment), the QDs had fluorescence emission maximum at $505-510 \mathrm{~nm}$ with a full width at half maximum about $35 \mathrm{~nm}$, and almost no phosphorescence signal, as shown in Figure 1. On the other hand, when this QD was heated to $90-100^{\circ} \mathrm{C}(\mathrm{pH} 11.4)$ for different periods of 
time, an increase in particle size as well as fluorescence and phosphorescence emission intensity was observed. Therefore, the heating period of three hours, which provided intense phosphorescence signal at longer wavelength, was selected to avoid fluorescence background emission from the biologic sample. The phosphorescence spectra of MPA-capped CdTe heated at different periods of time are shown in Figure 1.

The diameter of CdTe QD heated for 180 min (Figure 1) was calculated using the equation given below. ${ }^{27}$

$D=\left(9.8127 \times 10^{-7}\right) \lambda^{3}-\left(1.7147 \times 10^{-3}\right) \lambda^{2}+(1.0064) \lambda-194.84$

$D$ is the diameter of the nanocrystals $(\mathrm{nm}) ; \lambda$ is the wavelength corresponding to absorbance maximum determined as $560 \mathrm{~nm}$ from the UV-VIS spectrum, as shown Figure 2a. Calculations showed that the diameter of the MPA-CdTe QDs was $3.34 \mathrm{~nm}$. A TEM image of MPA-capped CdTe QDs is shown in Figure $2 \mathrm{~b}$. FTIR spectroscopy was used to confirm the modification of CdTe QDs with MPA molecules. The spectra of free MPA and MPA-CdTe are given in Figure 3a, 3b. The two bands at 2666 and $2570 \mathrm{~cm}^{-1}$, which is attributed to hydrogen bonding between acid and thiol groups, disappeared in the IR spectra of MPA capped-CdTe because the MPA is attached to QD through S-atoms. The small peaks that appeared at 2927, 2945, and $2854 \mathrm{~cm}^{-1}$ were attributed to the asymmetric and symmetric $\mathrm{C}-\mathrm{H}$ stretching of methylene groups. The appearance of an intense peak at $1570 \mathrm{~cm}^{-1} \mathrm{can}$ be attributed to asymmetric stretching of carboxylic acid.

The effect of $\mathrm{pH}$ and concentration of urease on phosphorescence intensity of MPA-capped CdTe QDs

$\mathrm{pH}$ is one of the important parameters that affects the photoluminescence intensity of the QDs. Therefore, the effect of the solution $\mathrm{pH}$ on the signal intensity of $\mathrm{QD}$ was studied using $0.5 \mathrm{~mL}$ of $0.04 \mathrm{M}$ Britton-Robinson buffer between $\mathrm{pH}$ 2.5-8.0. It was observed that the phosphorescence signal increased linearly as the $\mathrm{pH}$ increased from 2.5 to 5.0 , and decreased between $\mathrm{pH}$ 5.0-8.0. Therefore, a pH between 2.5-5.0 was selected for the determination of urea in the presence of $\mathrm{QD}$ and urease.

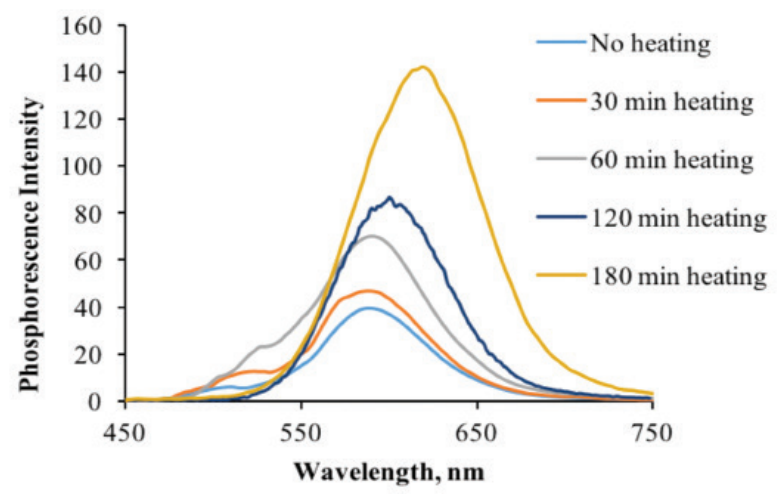

Figure 1. The effect of heating period on the phosphorescence signal of MPA-CdTe quantum dots. Excitation wavelength was $300 \mathrm{~nm}$, heating periods $30,60,120,180,240 \mathrm{~min}$ at $\mathrm{pH} 11.4$

MPA: 3-mercaptopropionic acid, CdTe: Cadmium telluride
Interestingly, the influence of $\mathrm{pH}$ on the fluorescence signal was different than the signal measured in the phosphorescence mode. The effect of $\mathrm{pH}$ on the photoluminescence intensity of MPA-CdTe QDs is shown Figure 4.

The effect of urease concentration was studied between 1-7.5 units $/ \mathrm{mL}$ in the presence of $0.24 \mathrm{mg} / \mathrm{L} \mathrm{MPA-CdTe}$ and $0.07 \mathrm{mM}$ urea. The maximum signal enhancement was observed when the urease concentration was 5 units $/ \mathrm{mL}$, which was then used throughout the experiments.

\section{Determination of urea}

Determination of urea is based on the production of ammonia in the presence of urease.

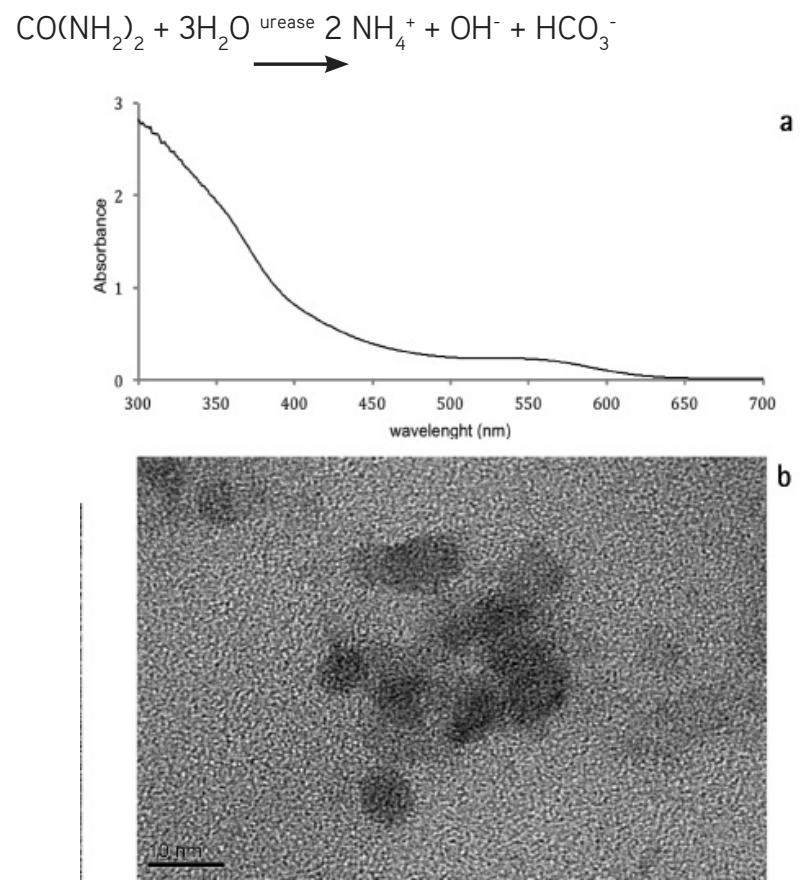

Figure 2. UV-VIS absorption spectrum of MPA-CdTe QDs given in Figure 1, the peak at $560 \mathrm{~nm}$ was used to calculate particle size (a) TEM image of the same QD (b)

UV-VIS: Ultraviolet visible, MPA: 3-mercaptopropionic acid, CdTe: Cadmium telluride, QDs: Quantum dots, TEM: Transmission electron microscopy

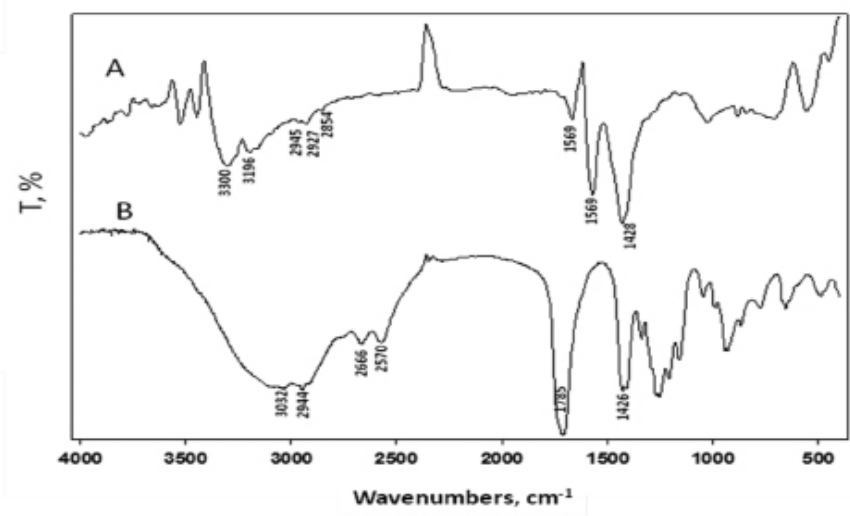

Figure 3. FTIR spectra of (a) MPA capped CdTe and (b) MPA alone FTIR: Fourier tansform infrared, MPA: 3-mercaptopropionic acid, CdTe: Cadmium telluride 
The $\mathrm{pH}$ of the medium is increased depending on the degradation of urea by urease. Consequently, the phosphorescence signal increased throughout the $\mathrm{pH}$ 2.5-5.0 range with increasing urea concentration. In the optimum conditions $(0.24 \mathrm{mg} / \mathrm{mL}$ CdTe-MPA, 5 units $/ \mathrm{mL}$ urease and $\mathrm{pH}$ 2.5), the calibration was constructed by plotting $\mathrm{I}-\mathrm{I}_{0}$ versus urea concentration $\left(\mathrm{I}_{0}\right.$ : phosphorescence signal of CdTe-MPA I: phosphorescence signal of CdTe - MPA + $0.0016-0.16 \mathrm{mM}$ urea). A linearity in phosphorescence signal was observed between $0.016-0.16$ $\mathrm{mM}$ urea concentrations. The phosphorescence signal with increasing urea concentration is shown Figure 5a. Although the fluorescence signal increased with urea concentration, the dynamic range was relatively narrow as shown in Figure $5 \mathrm{~b}$. The calibration curve based on phosphorescence signal is given in Figure 6.

The lifetime software of the instrument was used to obtain a decay curve for the phosphorescence emission and the data were used to construct a log intensity versus time graph. The lifetime of the QD was calculated using the -1/slope of this linear line and found as $21.5 \mu$ s. (Figure 7).

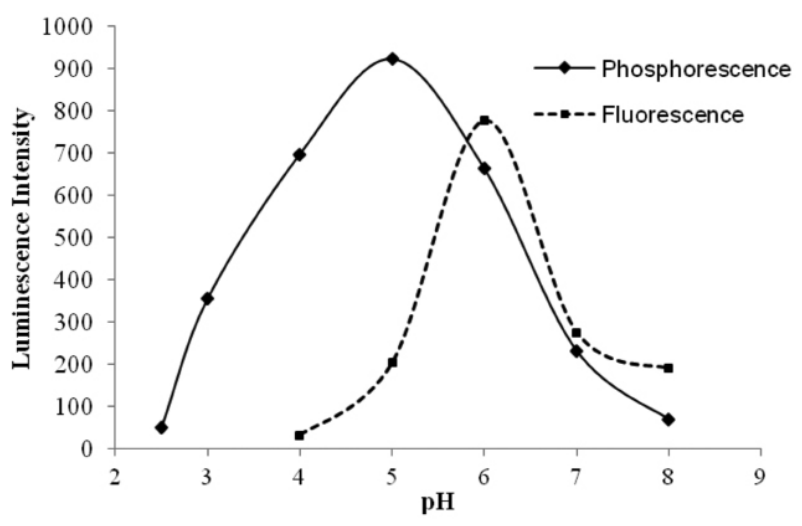

Figure 4. The effect of $\mathrm{pH}$ on luminescence intensity of MPA capped $\mathrm{CdTe}$ QDs. pH was adjusted using $0.5 \mathrm{~mL}$ of $0.04 \mathrm{M}$ Britton-Robinson buffer and diluted to $2.5 \mathrm{~mL}$

MPA: 3-mercaptopropionic acid, CdTe: Cadmium telluride, QDs: Quantum dots

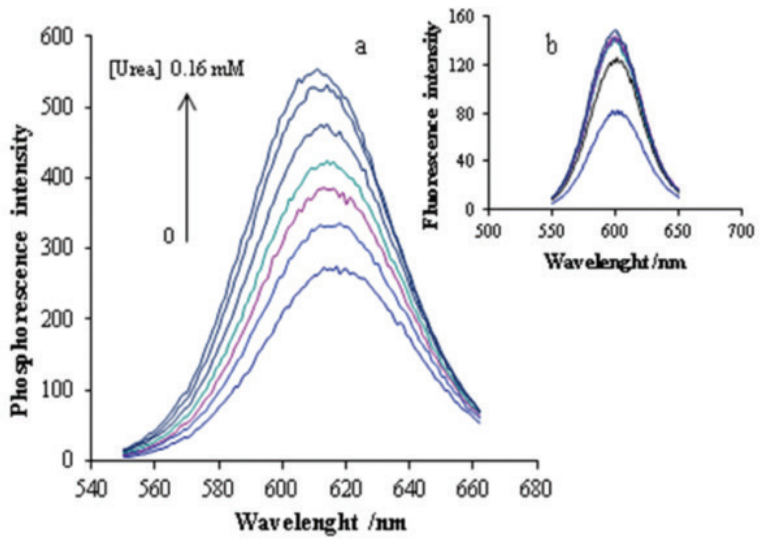

Figure 5. Enhancing photoluminescence signal with increasing urea concentration. Urea concentration 0-0.16 mM, urease concentration was 5 units $/ \mathrm{mL}$
The proposed method was compared with the methods in the literature. The limit of detection for the proposed method was lower or comparable with the methods such as fluorescence, amperometry, and potentiometry (Table 1). The analytical performance data of the method used for the determination of urea are given in Table 2 . The proposed method is relatively simple and free from the interference from the biologic matrix because the phosphorescence signal was used.

\section{Determination of urea in human serum}

Serum samples obtained from university laboratory were analyzed for urea using the proposed method. In order to test the accuracy of the proposed method, the same samples were analyzed in a private clinical laboratory; the results of which are shown in Table 3. The precision in terms of percent relative standard deviation, for three parallel determinations, was less than $6.7 \%$ and the urea concentrations were consistent with those reported.

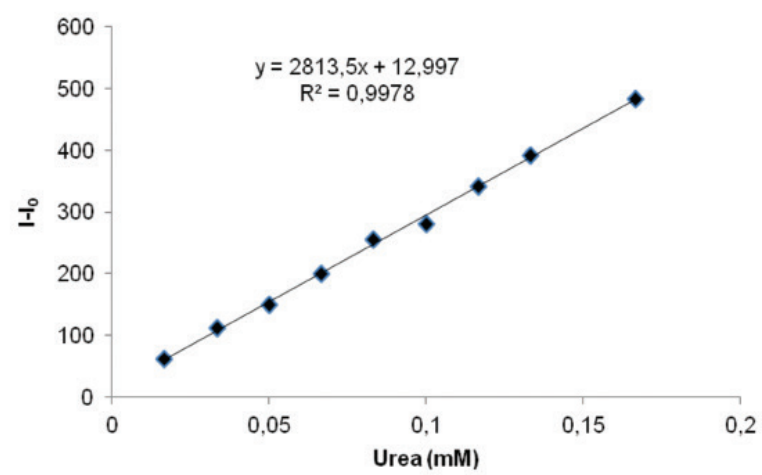

Figure 6. Calibration graph in the phosphorescence mode $\left(\mathrm{I}_{\mathrm{O}}\right.$ : Phosphorescence signal of MPA-CdTe, I: Phosphorescence signal of MPA$\mathrm{CdTe}+0.016-0.16 \mathrm{Mm}$ urea concentration)

MPA: 3-mercaptopropionic acid, CdTe: Cadmium telluride

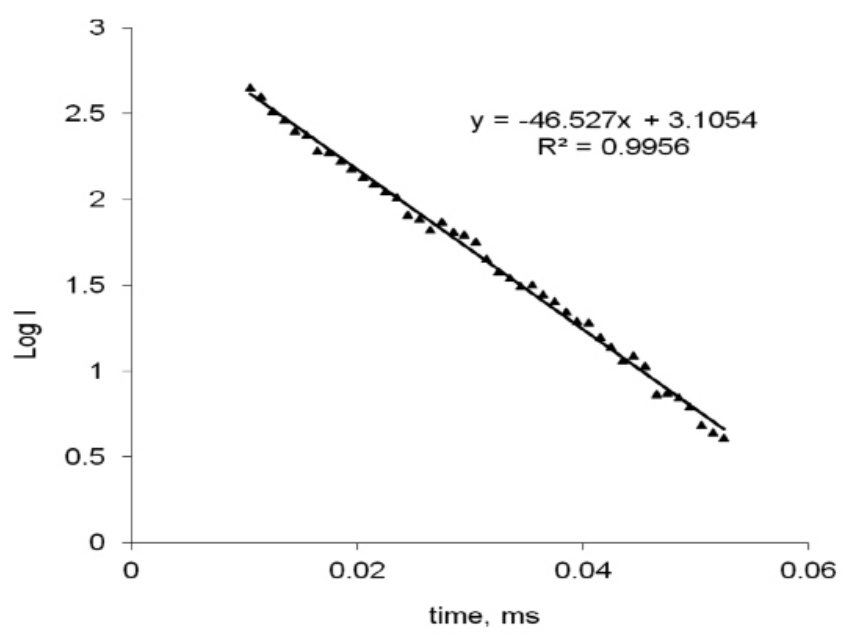

Figure 7. Lifetime measurements of the MPA-capped CdTe QDs, excitation and emission spectral band pass and the PMT voltage were $20 \mathrm{~nm}$ and 900 $\checkmark$, respectively

MPA: 3-mercaptopropionic acid, CdTe: Cadmium telluride, QDs: Quantum dots, PMT: Photomultiplier tube 
Table 1. Comparison of proposed methods with the methods in literature used for urea determination

\begin{tabular}{|c|c|c|c|c|}
\hline Method & Signal mechanism & Linear range, $\mathrm{mM}$ & LOD, mM & References \\
\hline Fluorescence & $\mathrm{CdSe} / \mathrm{ZnS}$-Urease & $0-10$ & - & 17 \\
\hline Fluorescence & CdSe/ZnSe-MSA-Urease & $0.01-100$ & 0.01 & 24 \\
\hline Amperometry & PVC ammonium electrode & $15-80$ & 15 & 5 \\
\hline Potentiometry & Urease polyurethane-acrylate & $0.2-0.6$ & 0.2 & 9 \\
\hline Phosphorescence & Mn doped ZnS QDs-Urease & $0.014-60$ & 0.014 & 6 \\
\hline Phosphorescence & MPA capped CdTe-Urease & $0.016-0.16$ & 0.003 & This work \\
\hline
\end{tabular}

Table 2. Analytical performance data of the method used for urea determination $(n=7)$

\begin{tabular}{ll} 
Linear range & $0.016-0.16 \mathrm{mM}$ \\
\hline LOD & $0.003 \mathrm{mM}$ \\
\hline SD & 0.13 \\
\hline RSD \% & $3.4 \%$ \\
\hline RE \% & -1.0
\end{tabular}

LOD: Logarithm of odds, SD: Standard deviation, RSD: Relative standard deviation, RE: Relative error

Table 3. Comparison of the urea concentration found in serum samples $(n=3)$

\begin{tabular}{lll} 
Sample & \multicolumn{2}{l}{ Found $( \pm \mathrm{s}), \mathrm{mM}$} \\
\cline { 2 - 3 } & CdTe-MPA & $\begin{array}{l}\text { Results from the private } \\
\text { clinical laboratory* }\end{array}$ \\
\hline Human serum 1 & $2.3 \pm 0.08$ & $2.50 \pm 0.03$ \\
\hline Human serum 2 & $2.5 \pm 0.02$ & $2.50 \pm 0.08$ \\
\hline Human serum 3 & $2.1 \pm 0.06$ & $2.16 \pm 0.08$ \\
\hline
\end{tabular}

*Blood urine nitrogen test based on a spectrophotometric method, CdTe: Cadmium telluride, MPA: 3-mercaptopropionic acid

\section{CONCLUSION}

It was shown that water-soluble and phosphorescent MPACdTe QDs can be used for the determination of urea in human blood serum samples. The proposed method is based on enzymatic degradation of urea by urease. In addition, the use of phosphorescence prevents interference such as scatter and autofluorescence from the sample matrix. Compared with conventional room temperature phosphorimetric methods, phosphorescent QDs provide a simpler methodology because no additional chemicals such as heavy atoms and oxygen removal processes are necessary. The results show that the proposed method is accurate, selective, rapid, and simple for urea determination in serum samples and can be applied to other biologic samples.

Conflict of Interest: No conflict of interest was declared by the authors.

\section{REFERENCES}

1. Chen JC, Chou JC, Sun TP, Hsiung SK. Portable urea biosensor based on the extended-gate field effect transistor Sens. Sens Actuators B Chem. 2003;91:180-186.

2. Azadbakht A, Gholivand MB. Covalent attachment of Ni-2,3-pyrazine dicarboxylic acid onto gold nanoparticle gold electrode modified with penicillamine- CdS quantum dots for electrocatalytic oxidation and determination of urea. Electrochimica Acta. 2014;125:9-21.

3. Usman Ali SM, Ibupoto ZH, Salman S, Nur O, Willander M, Danielsson B. Selective determination of urea using urease immobilized on $\mathrm{ZnO}$ nanowires. Sens Actuators B Chem. 2011;160:637-643.

4. Alizadeh T, Akbari A. A capacitive biosensor for ultra-trace level urea determination based on nano-sized urea-imprinted polymer receptors coated on graphite electrode surface. Biosens Bioelectron. 2013;43:321327.

5. Campanella L, Mazzei F, Sammartino MP, Tommassetti M. New enzyme sensors for urea and creatinine analysis. Bioelectrochemistry. 1990;23:195-202.

6. Bi L, Dong X, Yu Y. Room-temperature phosphorescence sensor based on manganese doped zinc sulfide quantum dots for detection of urea. $J$ Lumin. 2014;153:356-360.

7. Eggenstein C, Borchardt M, Diekmann C, Gründig B, Dumschat C, Cammann K, Knoll M, Spener F. A disposable biosensor for urea determination in blood based on an ammonium-sensitive transducer. Biosens Bioelectron. 1999;14:33-41.

8. Soldatkin AP, Montoriol J, Sant W, Martelet C, Jaffrezic-Renault N. A novel urea sensitive biosensor with extended dynamic range based on recombinant urease and ISFETs. Biosens Bioelectron. 2003;19:131-135.

9. Lakard B, Herlem G, Lakard S, Antoniou A, Fahys B. Urea potentiometric biosensor based on modified electrodes with urease immobilized on polyethylenimine films. Biosens Bioelectron. 2004;19:1641-1647.

10. Mizutani F, Yabuki S, Sato Y. Voltammetric enzyme sensor for urea using mercaptohydroquinone-modified gold electrode as the base transducer. Biosens Bioelectron. 1997;12:321-328.

11. Luo YC, Do JS. Urea biosensor based on PANi(urease)-Nafion/Au composite electrode. Biosens Bioelectron. 2004;20:15-23.

12. Lee WY, Kim SR, Kim TH, Lee KS, Shin MC, Park JK. Sol-gel-derived thick-film conductometric biosensor for urea determination in serum. Anal Chim Acta. 2000;404:195-203. 
13. Castillo-Ortega MM, Rodriguez DE, Encinas JC, Plascencia M, MéndezVelarde FA, Olayo R. Conductometric uric acid and urea biosensor prepared from electroconductive polyaniline-poly(n-butyl methacrylate) composites. Sens Actuators B Chem. 2002;85:19-25.

14. Chaudhari PS, Gokarna A, Kulkarni M, Karve MS, Bhoraskar SV. Porous silicon as an entrapping matrix for the immobilization of urease. Sens Actuators B Chem. 2005;107:258-263.

15. Huang CP, Li YK, Chen TM. A highly sensitive system for urea detection by using $\mathrm{CdSe} / \mathrm{ZnS}$ core-shell quantum dots. Biosens Bioelectron. 2007;22:1835-1838.

16. Tsai HC, Doong RA. Preparation and characterization of ureaseencapsulated biosensors in poly(vinyl alcohol)-modified silica sol-gel materials. Biosens Bioelectron. 2007;23:66-73.

17. Duong HD, Rhee Jl. Use of CdSe/ZnS luminescent quantum dots incorporated within sol-gel matrix for urea detection. Anal Chim Acta. 2008;626:53-61.

18. Weng J, Song X, Li L, Qian H, Chen K, Xu X, Cao C, Ren J. Highly luminescent $\mathrm{CdTe}$ quantum dots prepared in aqueous phase as an alternative fluorescent probe for cell imaging. Talanta. 2006;70:397-402.

19. Zhang $\mathrm{Y}$, Zhang $\mathrm{H}$, Guo $\mathrm{X}$, Wang $\mathrm{H}$. L-Cysteine-coated $\mathrm{CdSe} / \mathrm{CdS}$ coreshell quantum dots as selective fluorescence probe for copper(II) determination. Microchem J. 2008;89:142-147.

20. Singh SB, Limaye MV, Lalla NP, Kulkarni SK. Copper-ion-induced photoluminescence tuning in CdSe nanoparticles. J Lumin. 2008;128:1909-1912.

21. Liang J, Huang S, Zeng D, He Z, Ji X, Ai X, Yang H. CdSe quantum dots as luminescent probes for spironolactone determination. Talanta. 2006;69:126-130.
22. Frigerio C, Ribeiro DS, Rodrigues SS, Abreu VL, Barbosa JA, Prior JA, Marques KL, Santos JL. Application of quantum dots as analytical tools in automated chemical analysis: a review. Anal Chim Acta. 2012;735:922.

23. Murphy CJ. Optical sensing with quantum dots. Anal Chem. 2002;74:520A-526A.

24. Huang CP, Li YK, Chen TM. A highly sensitive system for urea detection by using $\mathrm{CdSe} / \mathrm{ZnS}$ core-shell quantum dots. Biosens Bioelectron. 2007;22:1835-1838.

25. Yu D, Wang Z, Liu Y, Jin L, Cheng Y, Zhou J, Cao S. Quantum dot-based $\mathrm{pH}$ probe for quick study of enzyme reaction kinetics. Enzyme Microb Technol. 2007;41:127-132.

26. Wang $Y Q$, Ye C, Zhu ZH, Hu YZ. Cadmium telluride quantum dots as $\mathrm{pH}$-sensitive probes for tiopronin determination. Anal Chim Acta. 2008;610:50-56.

27. Fortes PR, Frigerio C, Silvestre Cl, Santos JL, Lima JL, Zagatto EA. Cadmium telluride nanocrystals as luminescent sensitizers in flow analysis. Talanta. 2011;84:1314-1317.

28. He Y, Wang HF, Yan XP. Exploring Mn-doped ZnS quantum dots for the room-temperature phosphorescence detection of enoxacin in biological fluids. Anal Chem. 2008;80:3832-3837.

29. Wu P, He Y, Wang HF, Yan XP. Conjugation of glucose oxidase onto Mndoped $\mathrm{ZnS}$ quantum dots for phosphorescent sensing of glucose in biological fluids. Anal Chem. 2010;82:1427-1433.

30. Yuan J, Guo W, Yin J, Wang E. Glutathione-capped CdTe quantum dots for the sensitive detection of glucose. Talanta. 2009;77:1858-1863. 